\title{
Interrogating the Teaching and Learning of Chemistry in Nigerian Private Universities: Matters Arising
}

\author{
Mojisola O. Nkiko ${ }^{1}$ \\ ${ }^{1}$ Department of Physical and Chemical Sciences, Elizade University, Ilara-Mokin, Ondo State, Nigeria \\ Correspondence: Mojisola O. Nkiko, Department of Physical and Chemical Sciences, Elizade University, \\ Ilara-Mokin, Ondo State, Nigeria. E-mail: mojisola.nkiko@elizadeuniversity.edu.ng
}

Received: March 11, 2021 Accepted: April 20, 2021 Online Published: May 14, 2021

doi:10.5539/jel.v10n3p132 URL: https://doi.org/10.5539/jel.v10n3p132

\begin{abstract}
The indispensability and vast career possibilities associated with Chemistry notwithstanding, there is a palpable growing decline enrollment in Chemistry in Nigerian universities, particularly the private universities. The paper interrogated the teaching and learning of Chemistry in Nigerian private universities with a view to re-awakening the students' interest for effective mastery of the subject. It relied on secondary sources and critical analysis and found out that major inhibiting factors include: Students' faulty foundation in Chemistry, syndrome of area of concentration, absence of competitiveness in the admission process, poor attitude of students and lecturers as well as the ambience for effective scholarship. The paper concluded that the current downturn in the students enrolment in Chemistry and the seemingly poor interest in the subject portend sufficient threat to the future of Chemistry, chemical-related industries and the replacement of ageing Chemistry lecturers in Nigeria. It recommended the following strategies to mitigate the vicious cycle: targeted tutorial system, adoption of digital modes of teaching and learning, problem-based learning, capacity building initiatives for Chemistry lecturers, quality assurance mechanism, overhauling science education at the primary and secondary school levels, need-based assessment and provision of quality materials as well as adequate funding.
\end{abstract}

Keywords: teaching of chemistry, learning of chemistry, problem-based learning, Nigerian private universities, quality assurance

\section{Introduction}

Chemistry is central to every facet of life. It is the study of properties and composition of matter; its chemical reactions, structure and associated changes. It is primarily concerned with atoms and their interactions with other atoms, and particularly with the properties of chemical bonds. Chemistry is a science springing from the principles of physics with its applications in other sciences such as life-sciences, engineering, technology, earth sciences and medicine (Suchocki, 2014; Davies, 2008; Abanikannda, 2016; RSC, 2021). Chemistry graduates are engaged across the globe in rewarding careers in pharmaceutical, metallurgical firms, commercial laboratories, scientific research institutes, forensic scientists in the criminal justice system, universities, health services, food processing, petroleum and petro-chemical industry, biotechnology, toxicology, hazardous waste management, manufacturing industry, mining and extractive industry, medical technology, agriculture and forestry (Ababio, 2013; Helmenstine, 2019). The interdisciplinary nature of chemistry also lends its graduates to collaborating with engineers, physicists and biologists in proffering solutions to a wide spectrum of societal problems. Chemistry is globally adjudged a prerequisite subject for the study of engineering, medicine, other basic and applied science courses in any tertiary institution. Oloruntegbe and Oduntuyi (2008) averred that a student who is deficient in chemistry, and has good grades in other science subjects will hardly be able to offer any course in the faculties of science, medicine and engineering in the universities.

The ubiquity, pervasiveness, indispensability as well as vast career possibilities associated with chemistry notwithstanding, there is a palpable growing decline enrollment in Chemistry in Nigeria, particularly the private universities (Abanikannda, 2016). There are situations where only 4 students are enrolled and in other severe cases no enrollment at all. Several other studies have further established and documented the phenomenon of low enrolment in chemistry in the Nigerian tertiary institutions (Israel, 2005; Maduabum, 2005; Aina \& Akanbi, 2013; Aderemi, Hassan, Siyanbola, \& Taiwo, 2013; Osokoya, 2015). Glory (2020) alerted that chemistry was conspicuously missing from the list of 21 top sought after courses in Nigerian universities. The scenario 
obviously portends grave danger for future industrialization and science education in Nigeria. Oloyede (2004), Nja, Cornelius-Ukpebi, Edoho and Neji (2020) noted consistent poor performance of secondary school students in Chemistry and attributed the cause to defective teaching pedagogy. Chen (2013) observed that students' perception of Chemistry as a burden to be endured than as an experience to be valued results in phobia for Chemistry thereby impeding effective learning of the subject. Eddy (2000), hinted that a study in Malaysia revealed that many students perceived chemistry as too challenging, too abstract, boring and only tolerated because it is a compulsory subject for their preferred discipline. Other reasons identified for the dwindling interest and low level of performance in Chemistry include: insufficiency of qualified chemistry teachers, poorly equipped laboratories, poor study habits, lack of requisite infrastructure and poor funding (Gbore, 2006; Alam, Oloruntegbe, \& Orimogunje, 2010; Tafa, 2012; Kamisah \& Nur, 2013; Cox, 2019).

Transitioning dynamics from secondary schools to the university have implications for effective learning of chemistry. Jegede (2007); Adesoji and Olatunbosun (2008); Edomwonyi-out and Avaa (2011) and Emendu and Okoye (2015) aptly demonstrated that basic concepts were poorly learned prior to most students' admission into the university. There is therefore the need to properly interrogate the teaching and learning of Chemistry in Nigerian private universities with a view to discerning possible deficiencies and corrective mechanisms. The study is predicated on the necessity of perpetuating and transferring the knowledge of Chemistry to the next generation. It is aimed at re-awakening interest and providing enabling environment for effective mastery of the subject.

\section{Literature Review}

Teaching and learning of Chemistry revolve around the intricate interplay of passionate lecturers, willing and serious students, deployment of appropriate pedagogy, requisite facilities as well as a most enabling ambience for the actualization of a predetermined learning outcomes (Adesoji \& Olatunbosun, 2008; Emendu \& Okoye, 2015). This ideal scenario is however distorted by the prevalence of examination practices where students who had not engaged in meaningful learning coupled with lackadaisical attitude of some teachers thriving in a dysfunctional environment resort to diverse cheating techniques to obtain credit passes in Chemistry in the School Certificate Examinations (Angyaye, 2007). The illusion of obtaining credit pass in Chemistry rather than gaining mastery of the subject becomes the rat race. Many secondary schools in an attempt to please parents promote this malaise with the resultant effect of students gaining admission into the universities with the defective background and a false sense of achievement.

Corollary to the foregoing is the syndrome of alternative to practical chemistry introduced by schools with inadequate and ill-equipped laboratories for demonstration and experiments resorting to what is termed alternative to practical. The practice which is also tacitly endorsed by Examination Boards has the propensity of weakening the capabilities of the students for good experimental work. It reduces laboratory activities to an extension of the theoretical class rather than a place to carry out hands-on investigation. Chemistry practical is envisaged to enhance students understanding of scientific concepts; imbue in them scientific practical skills and problem-solving abilities (Adane \& Admas, 2011; Koller, Olufsen, Stojjanovska, \& Petrusevski, 2015). The practice of alternative to practical cannot sufficiently replace actual practical Chemistry classes. It stands to reason that students with such background will lack requisite independence and confidence for undertaking Chemistry at the university level.

Studies have equally shown that other issues militating against the effectiveness of teaching and learning of chemistry in Nigeria include: poor funding, lack of qualified teachers, problem of infrastructure, pedagogical problem, and phobia for chemistry, absence of and/or insufficient field trips, poor libraries and inadequate textbooks (Jegede, 2007; Edomwonyi-out \& Avaa, 2011; West African Examinations Council, 2014; Emendu \& Okoye, 2015; Abanikannda, 2016). Literature is replete with some strategies that have been adopted by other climes to facilitate improvement in the teaching and learning of chemistry. Yildizay and Leman (2017) reported the effectiveness of Problem-based Learning in the teaching of chemistry in Turkey. Yusuf (2017), Sadykov and Ctrnactova (2019) explored the impact of digital technologies on the teaching and learning of chemistry as well as providing amble evidences of the embedded capability of bridging identified gaps in knowledge. Digital technologies are now regarded as critical catalyst for improving, supporting, extending teaching and creative learning in higher education across the globe (Bell, Dempsey, \& Fister, 2015; Brown \& Malenfant, 2015; Horizon Report, 2015; Mabweazara, 2018). Kristen, Malinda, Monica and Kendra (2017) equally underscored the relevance of targeted tutorial aimed at providing special support to assist students overcome peculiar chemistry deficiencies and thus boost their confidence level for effective engagement. Finding real solution to the declining enrolment in Chemistry requires interrogating the teaching and learning of the subject with a view to understanding issues implicated thereof, or matters arising and then proffering strategies for effective 
intervention while taking cognizance of local peculiarities.

\section{Matters Arising}

\subsection{Foundational Problems Meditated by Area of Concentration}

Chemistry departments have inherited students with extremely unpleasant science education background from the national primary and secondary school system which bequeathed faulty foundation in basic chemistry to the new intakes. The university system now has preponderance of students who are grossly deficient in basic principles of general chemistry and lacking exposure to rudimentary conditions essential to laboratory practical. This phenomenon precipitated a culture shock on the university lecturers who had high expectations on the new intakes. To assuage their frustration some of the lecturers introduced the practice of "area of concentration". Students were given worked examples to memorise and the same were reproduced as test and examination questions culminating in phantom grades not representing the knowledge level and actual performance of the students. The students prefer lecturers who give them areas of concentration to the ones who insist on diligent understanding of principles, application of principles to real case scenarios, rigorous study and mastering the entire course coverage.

\subsection{Absence of Competitiveness in the Admission Process}

Apart from very few private universities that seem to be over-subscribed leading to intense selection for the best, most private universities have problem of enrolment and would offer a place to any applicant with minimum prerequisite and ability for sustainable tuition payment. This has the tendency of foisting on the system admixture of students, ranging from the brightest to the below average ones. Since the latter would find stiff competition for admission in the public universities, they seem to prefer the private universities. It requires extra efforts and techniques to impart knowledge to this category of students.

\subsection{Attitudes of Students and Lecturers}

Attitudes foster effective teaching and learning whether in public or private institutions. The lecturers' attitude is vital to shaping the learning experience of the students. The students will make conscious effort to be in class if the lecturer concerned has outstanding reputation, always prepared, focused and passionate about the lectures as well as devoting time in simplifying complex ideas and difficult concepts. Teaching Chemistry should be more than a job but an all-encompassing vocation to lecturers with appropriate attitudes. Unfortunately, persons who have no calling to the academia have been recruited as lecturers in the Nigerian University system. This category is not interested in molding and raising future generation of graduates but merely concerned about justifying their employment through "areas of concentration" syndrome and its resultant good examination grades effect. Those without genuine calling to the academia bring on board lackadaisical attitude to teaching, undue politicization and manipulation of the system leading to several distortions that are inimical to scholarship.

Similarly, some students who erroneously perceive the university as a place to obtain certificate rather than holistic education, show nonchalant attitude to the learning of Chemistry. They seem to lack the basic traits of observation and curiosity which are fundamental to learning the subject as well as detest the idea of impromptu tests and being called out to solve examples in class. They abhor homework preferring to copy completed assignments from their colleagues and avoid practice which leads to mastery in Chemistry. Effective learning and mastery of Chemistry require participatory attitude rather than passivity.

\subsection{Learning and Teaching Environment for Chemistry}

Stimulating and engaging environment provide necessary impetus for effective teaching and learning of Chemistry. This kind of ambience should be characterized by standard laboratory with current equipment, chemicals and other consumables. The working conditions and safety standards in the Chemistry laboratory must be above-average. The University Library in such an environment is adjudged to be well-stocked with current and relevant chemistry books as well as electronic resources. It is also expected that the classrooms are spacious, well ventilated, excellent lightning and cleanliness, availability of internet connectivity, functional air conditioner/fans, regular electricity as well as absence of hostility, sexual harassment, bullying and discrimination. Unlike their public counterparts, most private universities in Nigeria provide an empowering environment that should facilitate the teaching and learning of chemistry. This is indeed a necessary but not sufficient condition as other intervening variables must be optimized to achieve proper equilibrium and complementary effect on the scholarly activities of teachers and learners. Having x-rayed the matters arising in this discourse, there is therefore, the urgent need for appropriate strategies to be deployed in resolving the issues. 


\section{Strategies for Improvement}

It is obvious from the foregoing that the challenge of teaching and learning chemistry in the university stems from faulty Foundation inherited from the Nation's secondary school systems. To avoid the entrenchment of a vicious cycle the following strategies are recommended:

\subsection{Targeted Tutorial System}

Fresh students in the science, pharmacy, medicine, and engineering should be subjected to diagnostic test in chemistry to identify likely strength and weaknesses in the subject during the early weeks of resumption. The students adjudged to be weak in their foundational chemistry should undergo special remedial tutorials to strengthen their capability to cope effectively at the tertiary level. The unnecessary underlying assumption that mere possession of credit pass in chemistry at the school certificate level confers mastery is fraught with sweeping generalization. This is premised on the background that some of the students only have certificates that do not approximate to skills and sound education. Faulty Foundation has the propensity to drastically erode learning values and are symptomatic of phobia for chemistry and poor attitude towards class attendance as well as assignment.

\subsection{Adoption of Digital Mode of Teaching and Learning}

The conventional methods of lecture method, demonstration approach and discussion are no longer adequate for transmission of knowledge to students. The twenty-first century undergraduate students otherwise known as the millennial or digital natives favour different values and learning styles. The current generation of students are much better motivated by the concept of flipped classroom and blended model. The flipped classroom is a departure from the traditional mode of lecturers engaging in copious disperse of information to student using class time. It involves students having access to lecture materials from their portals, already studied same prior to the actual face-to-face lecture. This is the global best practice for teaching and learning virtually all subjects in the university. It is very effective because students have prior knowledge of the lecture contents and only come to class to clarify ambiguities, fill identified gaps in knowledge, ask relevant questions, and are able to understand concepts and principles better as well as concretize ideas previously gleaned from the materials. The flipped classroom system is normally complemented by the blended class model which involves a combination of learning in the form of watching video lectures, listening to podcasts, perusing enhanced e-book contents or online collaboration with peers and face-to-face classroom lectures. Mulholland and Bates (2014) noted that the adoption of digital models of teaching and learning empowers students with skills such as collaborative teamwork, problem solving, communication building, connections and innovation. The emergence of modern technologies has revolutionized teaching and learning hence the Nigerian university system must embrace the changes to meet the demands of the present generation.

\subsection{Problem-Based and Student-Centered Learning}

It is possible to have series of teaching sessions without learning taking place. The traditional idea of the dictation of lecture notes and working copious examples while the captive audience, the students watch, is not only anachronistic but leads to rote learning. Problem-based learning is a pedagogical approach that enables students to learn about a subject through solving problems in a collaborative setting as facilitated by the lecturer. It allows for self-directed habits through practice and reflection. It positions students as active knowledge seekers and co-creators who organize new relevant experiences and integrate same into prior knowledge (Yew \& Goh, 2016).

Practice leads to dexterity and mastery especially for quantitative-oriented subjects. Routine and regular practice remains pivotal in the learning of Chemistry. Students should be involved in hands-on solving of equations, working formulas, reviewing and working on sample chemistry tests. It is therefore gross fraud and disingenuous for a lecturer to give worked examples to students as areas of concern concentration; reproduce same verbatim as examination questions for students to memorize and regurgitate for high grades. Students must inculcate appropriate study habits which include reviewing and internalizing lecture materials before and after class, seeking understanding of concepts and learning the language of chemistry, maintaining good lecture notes, engaging in daily practice with online resources and sample exercises. The learning of chemistry requires the assimilation of many concepts and development of analytical skills as well as paying attention to instructions (Brown, LeMay, Bursten, Murphy, Woodward, \& Stoltzfus, 2017).

\subsection{Capacity Building Initiatives for Chemistry Lecturers}

The rapidity of changes in the fourth industrial revolution and especially in the higher education context, compels the need for capacity-building initiatives for Chemistry lecturers. To achieve sustainable teaching effectiveness in Chemistry in Nigerian private universities, there is the need to audit the knowledge and skills gap of the lecturers 
with a view to providing opportunities for continuous improvement. Obanya (2010) advocated for the need for occasional supervision and continuing pedagogical improvement opportunities for university lecturers to guarantee effective teaching and learning in the institutions. The Chemistry lecturer must be conversant with new digital modes of teaching and learning, current trends in curriculum and pedagogy as well as demand for emerging labour markets. It is crucial to find out if the lectures expose students to the twenty-first century skills of problem-solving, team work, initiative and enterprise, planning and organizing, self-management, communication, learning, computer literacy, presentation, networking, information literacy and marketing (Nkiko, 2018). Universities should deliberately sponsor lecturers to workshops, conferences, short trainings, and exchange programmes. The exposure will help hone their skills, knowledge, attitudes, abilities, and perspectives for greater effectiveness and productivity.

\subsection{Quality Assurance Mechanism}

The entrenchment of appropriate quality assurance mechanism in the university system to guarantee effectiveness and internal efficiency is crucial. This should transcend mere rhetoric, sloganeering and lip-service characteristic of many quality assurance activities of Nigerian universities. A virile quality assurance mechanism will be capable of monitoring and ensuring compliance to standards. Noticeable deviation from the expected input, processes and outputs will be reported to the Vice-chancellor and Senate for immediate intervention. Okebukola (2010) averred that "quality assurance covers activities an institution engages in to assure itself that it is on course to fulfilling its vision and mission in terms of input, process and output". The institutionalization of the mechanism will stem the tide of academic corrupt practices such as non-completion of course content in exchange for areas of concentration, gratification, and inducement to manipulate award of marks, lack of commitment by lecturers and students, non-adherence to staff or student ratio, non-provision of adequate and appropriate laboratory equipment (Okebukola \& Awah, 2019). The system will also adopt lecture monitoring and students' evaluation of lecturers as additional feedback mechanism. The whole essence of quality assurance is aimed at ensuring highest level of compliance with institutional policies, procedures, best practices and due diligence for outstanding outcomes. It is geared at making the lecturers and students to be productive, effective, excellent, and deploying best practices, as well as engage in continuous improvement.

\section{Conclusion and Recommendations}

The knowledge of Chemistry is critical and invaluable to the advancement of any society. The future of chemistry in Nigeria must be jealously protected if the nation will mainstream its scientific capabilities and industrialization into international standards. The current downturn in the students' enrolment in chemistry and the seemingly poor interest in the subject if not reversed would impact negatively on chemical-related industries as well as in the replacement of ageing chemistry lecturers. The interrogation of the teaching and learning of chemistry in Nigerian private universities has implicated some issues such as faulty foundation medicated by area of concentration, absence of competitiveness in the admission process, poor attitude of students and lecturers as well as the environment for the teaching and learning of chemistry. The strategies recommended for improvement in this study represent only partial solutions since they are limited in scope to the University system. A more holistic approach must extend to addressing the teaching and learning of science in primary and secondary schools. This is viewed against the background that deficiencies at this latter level have spiral negative effects on the teaching and learning of chemistry in the Nigerian universities. The Federal and State governments should commission a comprehensive study on the state of chemistry in Nigerian schools to appreciate the urgent need for funding, provision of quality materials, equipment and physical facilities as well as supportive environment to inspire interest in the learning of chemistry.

\section{References}

Ababio, O. (2013). New School Chemistry for Senior Secondary Schools. Nigeria. Africana First Publishers.

Abanikannda, M. (2016). Enhancing Effective Chemistry Learning Through Hypermedia Instructional Mode of Delivery. European Journal of Educational Research, 5(1), 27-34. https://doi.org/10.12973/eu-jer

Achor, E., Kurumah, S., \& Orokpo, C. (2012). Gender Dimension in Predictors of Students' Performance in MOCK-SSCE Practical and Theory Chemistry Examinations in Some Secondary Schools in Nigeria. Journal of Education, 2(2), 16-22. https://doi.org/10.5923/j.edu.20120202.04

Adane, L., \& Admas. (2011). Relevance and Safety of Chemistry Laboratory Experiments from Students' Perspective: A Case Study of Jimma University. Southwestern Ethiopia. Education Research, 2(12), $1749-1758$.

Aderemi, H. O., Hassan, O. M., Siyanbola, W. O., \& Taiwo, K. (2013). Trends in Enrollment, Graduation and 
Staffing of Science and Technology Education in Nigeria Tertiary Institutions. A Gender Participation Perspective, 8(2), 11-20.

Adesoji, F. A., \& Olatunbosun, S. M. (2008). Student, Teacher and School Environment Factors as Determinants of Achievement in Senior Secondary School Chemistry in Oyo State, Nigeria. The Journal of International Social Research, 1(2), 13-34.

Aina, J. K., \& Akanbi, A. G. (2013). Perceived Causes of Students' Low Enrolment in Science in Nigerian Secondary Schools. International Journal of Secondary Education, 1(5), 18-22. https://doi.org/10.11648/j.ijsedu.20130105.11

Alam, G., Oloruntegbe, O., \& Orimogunje, P. (2010). Comparative Evaluation of the Effectiveness of 2D and 3D Visualizations in students' Understanding of structures of Organic Molecules. International Journal of Physical Science, 5(5), 32-35.

Angyaye, C. (2007). Information and Communication Technology. A Paper presented at the Conference on Examination Security in Nigeria, Abuja.

Bell, S., Dempsey, L., \& Fister, B. (2015, March 17). New Roles for the Road Ahead: Essays commissioned for the ACRL's 75th Anniversary. Retrieved from http://www.ala.org/acrl/sites/ala.org.acrl/files/content/publications/whitepap rs/new_roles_5th.pdf

Brown, C., \& Malenfant, K. (2015). Academic library contribution to student success document practices from the field. Association of College and Research Libraries (ACRL). Retrieved from http://www.ala.org/contributionreport.pdf

Brown, T., LeMay, H., Bursten, B., Murphy, C., Woodward, P., \& Stoltzfus, M. (2017). Chemistry: The Central Science (14th ed.), Pearson International.

Chen, C. S. H., (2013). Assessment of Chemistry Anxiety among College Students. In M. H. Chiu, H.-L. Tuan, H.-K. Wu, J.-W. Lin \& C.-C. Chou (Eds.), Chemistry Education and Sustainability in the Global Age (pp. 27-34). Springer Science. https://doi.org/10.1007/978-94-007-4860-6_3

Cox, J. (2019). How to Motivate Students to Love Science. K-12 News, Lessons \& Shared Resources by $\begin{array}{llllll}\text { Teachers, For } \quad \text { Teachers. } & \text { Educational }\end{array}$ https://www.teachhub.com/howmotivate-students-love-science

Davies, P. (2008). Organometallics: Transition Metals in Organic Synthesis. Organic Chemistry, 104(1), 68-87. https://doi.org/10.1039/b716606k

Eddy, R. (2000). Chemophobia in the College Classroom: Extent, Sources and Student Characteristics. Journal of Chemical Education, 77(4), 514-517. https://doi.org/10.1021/ed077p514

Edomwonyi-otu, L., \& Avaa, A. (2011). The challenge of effective teaching of chemistry: A case study. Leonardo Electronic Journal of Practices and Technologies, 10(18), 1-8.

Emendu, N., \& Okoye, C. (2015). Identifying Problems Associated with Studying of Chemistry in Anambra State, Nigeria. International Journal of Scientific and Research Publications, 5(6), 1-7.

Gbore, L. (2006). Cognitive Entry Characteristics Study Habits and Self-concept as Predictor of Academic Performance of University Undergraduate Students in South West Nigeria. Unpublished Ph.D. Thesis. University of Ekiti, Nigeria.

Glory, J. (2020). Most Preferred/Sought After Courses in Nigerian Universities/Polytechnics. Retrieved from https://www.dailyschoolnews.com.ng/most-preferredsought-after-courses-in-nigerianuniversitiespolytechni $\mathrm{cs} /$.

Helmenstine, A. M. (2019). Why Study Chemistry? Retrieved from http://www.thoughtco.com/science-4132464

Horizon Report. (2015). The NMC Horizon Report: 2015 Higher Education Edition. Retrieved from http://www.net.educause.edu/ir/HR2015.pdf

Israel, J. A. (2005). Causes of Students Low Enrolment in Chemistry: A Case Study of Federal College of Education (Technical) Umunze. Journal of Empirical Research in Science and Technology Education, 1(1), $32-41$.

Jegede, S. (2007). Students' Anxiety towards the Learning of Chemistry in Some Nigerian Secondary Schools. Educational Research and Review, 2(7), 193-197.

Kamisah, O., \& Nur, S. (2013). Conceptual Understanding in Secondary School Chemistry: Discussion of 
Difficulties Experienced by Students. American Journal of Applied Sciences, 10(5), 433-441. https://doi.org/10.3844/ajassp.2013.433.441

Köller, H.-G., Olufsen, M., Stojanovska, M., \& Petrusevski, V. (2015). Practical work in chemistry and its goals and effects. Chemistry in Action, 106, 37-50.

Kristen K. B., Malinda, W. G., Monica, D., \& Kendra, M. (2017). Pedagogical Methods and Technology Used in Chemistry Secondary Education. Modern Chemistry \& Applications, 5(3), 223. https://doi.org/10.4172/2329-6798.1000223

Mabweazara, R. (2018). The 21st century Academic Library. The case of three state universities in Zimbabwe. Unpublished Ph.D Thesis. University of the Western Cape Bellville, South Africa.

Maduabum, M. A. (2005). Women Empowerment through Access to Science, Technology and Mathematics (STM) University Education in Nigeria: Rationale, Current Status and Strategies for Improvement. Paper Presentation. International Conference on "Tertiary Institutions, Women's Health and Education". Imo State University, Owerri.

Mulholland, E., \& Bates, J. (2014). Use and Perceptions of E-books by Academic staff in Further Education. Journal of Academic Librarianship, 40(5), 492-499. https://doi.org/10.1016/j.acalib.2014.05.018

Nja, O. C., Cornelius-Ukpebi, B., Edoho, E. A., \& Neji, H. A (2020). Enhancing Students' Academic Performance in Chemistry by Using Kitchen Resources. Educational Research Reviews, 15(1), 19-26. https://doi.org/10.5897/ERR2019.3810

Nkiko, C. (2018). Maintaining Relevance and Effectiveness as an Academic for Global Competitiveness. Paper Presentation. Samuel Adegboyega University Mentoring and Chat Series. Ogwa-Edo State.

Obanya, P. (2010.) System Re-engineering and Institutional Re-branding for Building a World class University: The Nigerian Perspective. Paper Presentation. Fourth Annual Lecture of Professor Grace Mbipom Foundation, University of Calabar, Nigeria.

Okebukola, P. (2010). Fifty Years of Higher Education in Nigeria: Trends in Quality Assurance. Paper Presentation. International Conference on the Contributions of Nigerian Universities to the 50th Independence Anniversary of Nigeria.

Okebukola, P., \& Awah, F. (2019). Combating Academic Corruption to Improve Quality in African Higher Education. Paper Presentation. 11th International Conference and Workshops on Quality Assurance in Higher Education in Africa. Abuja, Nigeria.

Oloruntegbe, K., \& Oduntuyi, M. (2008). An Innovative Information and Communication Technology (ICT) based Approach to the Teaching and Learning of Chemistry. Pakinstian Journal of Social Sciences, 54(1), 317.

Oloyede, O. (2004). Effect of Small Group Instructional Techniques on Chemistry Achievement of SSS Slow Learners. ABUJOUS, 2(2), 34-39.

Osokoya, M. M. (2005). Career Aspiration of Chemistry Undergraduates in Nigerian Universities: Pattern and Factors. Nigerian Journal of Chemical and Counselling Psychology, 15(1), 22.

RSC. (2021). Definition in Chemistry. Retrieved from http://edu.rsc.org/resources/definition-inchemistry/1088.article

Sadykov, T., \& Ctrnactova, H. (2019). Interactive Lessons with ICT in Chemistry Education. International Conference on the Methods of Science Education Proceedings. https://doi.org/10.36007/eruedu.2020.1.095-110

Sözbilir, M., \& Bennett, J. M. (2007). A study of Turkish chemistry undergraduates' understanding of entropy. Journal of Chemical Education, 84(7), 1204-1208. https://doi.org/10.1021/ed084p1204

Suchocki, J. (2014). Conceptual Chemistry (5th ed.). Pearson International.

Taber, K. (2002). Conceptualizing Quanta: Illuminating the Ground State of Student Understanding of Atomic Orbitals. Chemistry Education, Research and Practice, 3(1), 145-158. https://doi.org/10.1039/B2RP90012B

Tafa, B. (2012). Laboratory Activities and Students' Practical Performance: The Case of Practical Organic Chemistry. African Journal of Chemistry Education, 2(3), 68

West African Examination Council. (2014). Chief Examiners' Reports in Nigeria by the West African 
Examinations Council.

Yew, E., \& Goh, K. (2016). Problem-based Learning: An Overview of Its Process and Impact on Learning. Health Professions Education, 2(2), 75-79. https://doi.org/10.1016/j.hpe.2016.01.004

Yildizay, A., \& Leman, T. (2017). Problem-based Learning in Teaching Chemistry: Enthalpy Changes in Systems. Research in Science \& Technological Education, 36(1), 35-54. https://doi.org/10.1080/02635143.2017.1366898

Yusuf, Y. (2017). Learning Chemistry by ICT (Virtual Animation) at Maumere High School, East Nusa Tenggara. Journal of Education, Teaching and Learning, 2(1), 67. https://doi.org/10.26737/jetl.v2i1.138

\section{Copyrights}

Copyright for this article is retained by the author, with first publication rights granted to the journal.

This is an open-access article distributed under the terms and conditions of the Creative Commons Attribution license (http://creativecommons.org/licenses/by/4.0/). 